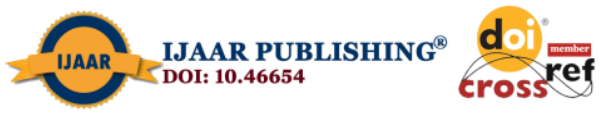

Research Journal of Management Practice | ISSN: 2782-7674

Vol. 1, Issue 4 (April, 2021) | www.ijaar.org

Journal DOI: $w$ ww.doi.org/10.46654/RJMP

Article DOI: www.doi.org/10.46654/RJMP.1410

\title{
THE IMPERATIVE OF ACCOUNTING ETHICS IN THE ADOPTION OF FRAUD PREVENTIVE MEASURES IN NIGERIA
}

\author{
Solomon Kumai Ngu \\ Department of Accounting, Faculty of Social and Management Sciences, \\ Greenfield University Kasarami, Kaduna, Nigeria. \\ Email: Solomon.ngu@gfu.edu.ng
}

\begin{abstract}
This study examined the imperative of accounting ethics in adopting fraud preventive measures in Nigeria. To achieve this objective, the survey research design was adopted while primary data was sourced through structured questionnaire. Data collected were analyzed using Descriptive statistical tools (tables, frequency distribution and percentages) and Spearman's Nonparametric Correlation. It was discovered that the effectiveness of other fraud preventive measures depends to a large extent on the level of ethical compliance by accountants. Findings also revealed that compliance with ethical codes is an effective way to prevent fraud. Hence, strict enforcement by relevant professional bodies will increase the compliance level, thereby reducing the incidences of fraud in Nigeria. It was concluded that accounting ethics plays significant role in the adoption of fraud preventive measures in Nigeria. Therefore, it is recommended that organizations should adopt measures that will encourage accountants to discharge their responsibilities in accordance with the requirements of the ethical code without undue influence or pressure from management. Furthermore, accounting bodies should put in place strict monitoring and disciplinary measures that will ensure compliance with ethical principles. This will restore the confidence and reputation of the accounting profession as trustees and watchdogs of the society.
\end{abstract}

Key words: Accounting ethics, fraud, fraud prevention 
Journal DOI: www.doi.org/10.46654/RJMP

Article DOI: www.doi.org/10.46654/RJMP.1410

\section{INTRODUCTION}

The rate of accounting fraud and corporate scandals globally is an issue of concern due to its devastating effects on the economy. High profile organisations in the United Kingdom such as Independent Insurance and BCCI were involved in corporate scandals. The United States of America (USA) had also experienced the collapse of big corporate organisations such as Enron Corporation, Tyco International, WorldCom, Global Crossing, and Arthur Anderson among others (Ogbonna and Appah, 2011). According to Yinka, Jide and Emmanuel (2015), Nigerian corporations such as Cadbury Nig. Plc, NAMPAK, Afri-Bank and Lever brothers (Nig.) were also involved in different fraud scandals. These scandals have led to the loss of billions of dollars of shareholders value and reduced investors and public confidence in accounting reports and financial markets.

The accounting profession has suffered scrutiny and criticism as a result of the increase in fraudulent practices and corporate scandals. The confidence repose on the accountant as a 'watch dog' of the society is fading away. Vital economic and business decisions are made by users of accounting information on the basis of the information provided by the accountant. Fraudulent accounting information leads to wrong or inappropriate decisions by companies' owners, management, investors and other stakeholders.

Consequently, different fraud preventive measures have been adopted by different countries including Nigeria, and many more are been envisaged to stop or reduce this cankerworm called fraud in both the public and private sectors of the economy. The United States of America for instance enacted the Sarbanes Oxley Act of 2002 in response to the corporate scandals of the late 1990s and early 2000s, which resulted in major losses for investors and a decline in investors' confidence in the U.S capital market (Center for Audit Quality, 2010). These frauds preventive measures are necessary because according to Abdullahi and Mansor (2015), it is less expensive and more effective to prevent fraud from happening than to detect it after the occurrence. Usually, by the time the fraud is discovered, the money or asset may be unrecoverable or the chance of full recovery of the amount may be very slim. Furthermore, it is expensive and time consuming to investigate fraudulent activities especially involving multinational concerns. However, if the focus is on fraud prevention, all the financial losses, time and effort to track fraudulent transactions, track down perpetrators, and recover missing funds can be saved.

Accounting ethics is one of the major and most effective fraud preventive measures been advocated to ensure the effectiveness of other fraud preventive measures. Ethical compliance by accountants becomes essential due to the nature of work carried out by them as stewards and custodians of funds, as well as professional services rendered by them. Just like most professions, the accounting profession is supposed to maintain high ethical standards which will enable accountants provide reliable information and design mechanisms for fraud prevention. Hence, this study aims at examining the imperative of accounting ethics in adopting fraud preventive measures in Nigeria.

\section{Statement of the Problem}

The role of the accounting profession in business and in modern society cannot be overemphasized. Accountants provide information needed by users of accounting information to 
Journal DOI: www.doi.org/10.46654/RJMP

Article DOI: www.doi.org/10.46654/RJMP.1410

make informed decisions. Furthermore, accountants are custodians of funds both in the public and private sector of the economy. As custodians and trustees, they are expected to exhibit high level of professional ethics and fraud preventive skills. However, some of the corporate scandals and fraudulent acts have been linked to accountants. It has been argued that accountants use their knowledge and skills to manipulate financial information.

The Economic and Financial Crimes Commission (EFCC) and the Independent Corrupt Practices Commission (ICPC) were established in Nigeria to curb fraud and financial crimes. Policies such as the Treasury Single Account (TSA) have also been put in place in order to prevent the occurrence of fraud. Despite these measures, the rate at which fraud is being perpetrated in Nigeria is still high, with some accountants directly involved or aiding it. This has stained the accounting profession and has questioned the level of ethical compliance by accountants.

Previous studies such as Okaro, Okafor and Ofoegbu (2013); Eme, Inyang and Udeme (2016); Gbegi and Adebisi (2015); and Javiriyah (2011) were conducted on the causes of fraud and fraud preventive measures in Nigeria. However, little attention has been given to the role of accounting ethics in the adoption of fraud preventive measures. Hence, the following questions are raised:

I. Does accounting ethics play significant role in the adoption of fraud preventive measures in Nigeria?

II. Does compliance with ethical codes by accountants prevent the occurrence of fraud?

\section{Objectives of the Study}

The main objective of this study is to examine the imperative of accounting ethics in the adoption of fraud preventive measures in Nigeria, while the specific objectives are:

I. To determine whether accounting ethics play significant role in the adoption of fraud preventive measures in Nigeria.

II. To determine whether compliance with ethical code by accountants prevents the occurrence of fraud.

\section{Research Hypotheses}

Ho1 Accounting ethics does not play significant role in the adoption of fraud preventive measures in Nigeria.

Ho2 Compliance with ethical codes by accountants does not prevent the occurrence of fraud

\section{LITERATURE REVIEW}

\section{The Concepts of Ethics and Accounting Ethics}

Ethics are moral principles and values that guide or govern the conduct of an individual, group, organisation or profession. According to Ogbonna and Appah (2011); Nwagboso (2008); Otalor and Eiya (2013), ethics is a criteria by which an individual distinguishes what is right or wrong. 
Journal DOI: www.doi.org/10.46654/RJMP

Article DOI: $\underline{\text { www.doi.org/10.46654/RJMP.1410 }}$

Ethics and ethical values border on our sense of morality, our sense of right and wrong. It centers on how we think, how we do things and what we say. According to Otalor and Eiya (2013), ethics is concerned with norms, principles, ground rules, values or behavioral conducts and practices exhibited by an individual, a group of people, community or profession. It is an acceptable standard of behavior or unwritten regulations or moral principles that guides an individual, an organization, a profession or society in their dealings with one another.

Nwagboso (2008) asserts that ethics is in a state of ferment and chaos in the society. He further asserts that ethics is not about what we were, what we are or even what we will be. It is what ought to be, which should be the standard by which we judge character and action.

Accounting ethics therefore, refers to the principles, norms, values and standards that guide the conduct of accountants and the practice of the accounting profession. According to Nwagboso (2008), accounting is a profession that requires a high sense of responsibility and stewardship, and this stresses the need for members of the profession to be guided by ethical codes of conducts. Ogbonna and Appah (2011) assert that ethical compliance by business people in general and the accountant in particular is not an option or discretionary, but a necessity for the smooth running of an organization and for fraud prevention. This has renewed interest in the issue of ethics in the accounting profession. Neringa and Justina (2013) argue that insufficient or inappropriate understanding of ethical principles or wrong interpretation of ethical codes by accountants can lead to unethical behavior and fraud.

According to International Ethics Standards Board for Accountants (2018), Nwagboso (2008), and ICAN (2014), the fundamental principles of ethics (also known as code of ethics) applicable to accountants include the following:

Integrity: According to International Ethics Standards Board for Accountants (2018), to maintain and broaden public confidence, professionals should perform all professional responsibilities with the highest sense of integrity. Integrity is an essential ingredient to professional recognition. Integrity requires accountants to be honest, sincere, straightforward and transparent in professional and business dealings. According to Nwagboso (2012), integrity is the basis for which public trust is derived and a benchmark against which decisions must be tested by the accountant. International Ethics Standards Board for Accountants (2018) opine that a professional accountant shall not knowingly be involved with reports, returns, communications or other information, where the accountant believes that the information contains a materially false or misleading statement; information furnished recklessly; or omits or obscures information required to be included where such omission or obscurity would be misleading. According to ICAN (2014), example of lack of integrity in business might be where an accountant helps to cover up a fraud with false accounting entries.

Objectivity: According to International Ethics Standards Board for Accountants (2018), the principle of objectivity imposes an obligation on all professional accountants not to compromise their professional or business judgement because of bias, conflict of interest or the undue influence of others. An accountant should avoid any service, relationship, influences or act that can affect or influence the accountant's professional judgment with respect to that service. According to ICAN (2014), example of an objective accountant in business is in the preparation 
Journal DOI: www.doi.org/10.46654/RJMP

Article DOI: $\underline{\text { www.doi.org/10.46654/RJMP.1410 }}$

of prepayments, accrual and provision journals at month or year end. They should reflect the true state of affairs rather than an attempt to manage earnings and manipulate profit or tax figures.

Professional Competence and Due Care: This principle entails a sense of duty, accuracy and skills. According to International Ethics Standards Board for Accountants (2018), the principle of professional competence and due care imposes on the accountant the obligation to maintain professional knowledge and skill at the level required to ensure that clients or employers receive competent professional service, and to act diligently in accordance with applicable technical and professional standards. Competent professional service requires the exercise of sound judgment in applying professional knowledge and skill in the performance of such service. According to ICAN (2014), professional accountants have a duty to carry out the instructions of an employer or client with care and skill provided these are in line with the ethical requirements of integrity, objectivity and (in the case of accountants in public practice) independence.

Confidentiality: A professional accountant should respect the confidentiality of information acquired from the client in the course of performing professional services (Ogbonna and Appah, 2011). According to International Ethics Standards Board for Accountants (2018), the confidentiality principle refrains an accountant from disclosing outside the firm or employing organization confidential information obtained in the course of professional and business relationships without any authority to do so or a legal or professional right and duty to disclose. The principle also refrains the accountant from using confidential information acquired as a result of professional and business relationships to their personal advantage or the advantage of third parties.

Professional Behavior: Accountants are required to observe relevant laws and regulations, and to avoid any act that would discredit the accountancy profession (ICAN, 2014). According to International Ethics Standards Board for Accountants (2018), this includes actions that a reasonable and informed third party, weighing all the specific facts and circumstances available to the accountant at that time, would be likely to conclude adversely affects the good reputation of the profession.

\section{Corporate and Accounting Fraud}

Fraud is an issue of concern in Nigeria and other parts of the world, due to its devastating effect on the economy. Fraud according to Reynolds and Gavagni (2015) is defined as intentional pervasion of truth with the aim of inducing another to part with something of value or to surrender a legal right. It is a wrongful or criminal deception intended to result in financial or personal gain. According to Enofe, Okpako and Atube (2013), fraud refers to the intentional misrepresentation of the truth in order to manipulate or deceive an individual or organization. Fraud aims at creating a misjudgment or maintaining an existing misjudgment to induce an individual or organization to a contract. It involves intentional enrichment of oneself by reducing the value or worth of an asset in secret.

According to James (2004), for an act to be regarded as fraudulent, five conditions must be present: false representation (some misrepresentation or omission must have occurred); material fact (it must matter); there must be the intention to deceive; justifiable reliance (it should affect someone's decision); and injury or loss must have occurred. 
Journal DOI: www.doi.org/10.46654/RJMP

Article DOI: $\underline{\text { ww.doi.org/10.46654/RJMP.1410 }}$

Accounting fraud according to Nickolas (2015) is an intentional manipulation of financial statements to create a facade of a company's financial health. This involves an employee, accountant or the organization itself which can mislead investors, and other stakeholders. A company or organization can falsify its financial statements by overstating its revenue or assets, not recording expenses, and under-recording liabilities. Okwuduche (2016) opines that accounting fraud is a situation where an employee of a business entity or organization steals, misappropriate or embezzle money or other resources. Unit managers, accounting clerks or chief financial officer can perpetrate this kind of fraud.

Ernst \& Young (n.d), James (2004), Reynolds and Gavagni (2015), and Adeniji (2004) summarized the types of fraud on the basis of methods of perpetration to include the following:

Misappropriation of Assets. This type of fraud includes theft or misuse of tangible and intangible assets and fraudulent expenditures. Fraudulent expenditures may include payroll fraud, employee expense fraud and cash skimming.

Fraudulent Financial Statements. This type of fraud includes misstatement or omission of material information/accounting records from financial statements; improper capitalization/deferral of expenses; improper revenue recognition; asset/liability manipulation; and improper manipulation of tax accounts.

Corruption Schemes. This involves utilizing influence in business transactions to obtain a personal benefit; bribery and/or extortion; aiding and abetting fraud.

Many factors could be responsible for fraud perpetration by accountants, other employees and management of an organization. These are summarized into three components commonly known as the fraud triangle.

\section{The Role of Accounting Ethics in Fraud Prevention In Nigeria}

Different fraud preventive measures are been adopted both in the public and private sector due to the devastating effect of fraud on organisational survival and the economy. According to Hamilton and Gabriel (2012), Nigeria as a country is deeply soaked in, and characterized by fraud and its related corrupt practices. This has resulted in severe negative consequences on the country and its global image.

Corporate and accounting fraud has dominated the headlines of mainstream national news over the years. Accounting fraud is becoming too frequent, forcing earnings restatements, and having a huge effect on companies' books, the financial markets, and most critically, the overall economy. This has drawn the attention of investors, analyst and regulators (Mock, 2004). According to Otusanya, Lauwo and Hayati (2012), accountants and accounting practices are key in fraud prevention. Because fraud often involves financial payment in one form or another, asset misappropriation or accounting information falsification and manipulation. Hamilton and Gabriel (2012) assert that accountants and auditors have often been exalted to be leaders in fraud prevention, by utilizing their skills in designing tight control systems. This strategy however, is not sufficient to prevent fraud. This is because business activities are built on the trust that people at all levels will do their jobs properly. 
Journal DOI: www.doi.org/10.46654/RJMP

Article DOI: $\underline{\text { www.doi.org/10.46654/RJMP.1410 }}$

According to Abiola and Oyewole (2013), fraud cannot be eradicated completely, but it can be minimized. Fraudsters have different methods of perpetrating fraud, hence, there may be no unique approach to prevent fraud. However, the common fraud preventive measures according to Abiola and Oyewole (2013), Hamilton and Gabriel (2012), Ernst \& Young (n.d), Eme, Inyang and Udeme (2016), and Akani and Oladutire (2013) include effective and strong internal controls, effective internal and external audits, fraud training and awareness, implementing policies and procedures that will minimize the opportunity and pressure to commit fraud and strict adherence to ethical code of conduct.

Accounting ethics is essential because all other fraud preventive measures can only be effective if accountants adhere to their ethical code of conduct. This is because accountants are the custodians of the financial resources and assets of organisations, and also provide accounting information to interested parties. For instance, the internal controls are usually designed by accountants, and the effectiveness of which depends on the integrity and professional competence of the accountant. Hamilton and Gabriel (2012) argue that accountants and auditors are in position to prevent fraud by employing their skills in designing an effective internal control system. The effectiveness of the internal and external audit also depends on the adherence to accountants' ethical code. This will provide truthful and reliable financial reports and also boost the confidence of users. Also, in conducting fraud training and awareness, the emphasis should be on the adherence to ethical code by accountants and business ethics by other employees of an organization.

\section{Theoretical Framework}

The theoretical underpinning of this study is basically the deontological theory of ethics, the fraud triangle theory and the fraud diamond theory.

Deontological Theory of Ethics: The word 'deontological' comes from the Greek Deon, meaning 'duty'. According to Ronald (n.d), deontological theory is by definition duty based. That is to say, an action or decision is ethical if it will fulfill moral obligations, or duties. Duties, in the deontological tradition are most often associated with obeying absolute moral rules or universal principles. Hence, human beings are morally required to do (or not to do) certain acts in order to uphold a rule, law or standard. The focus of this theory is on doing what is right in line with the established principles, standards or rules rather than what will maximize societal welfare as in utilitarianism.

Fraud Triangle Theory: According to Abdullahi and Mansor (2015), Donald Cressey, a criminologist, started the study of fraud in 1950. In his study, he argued that there must be a reason behind everything people do. Questions such as why people commit fraud led him to focus his research on what drives people who accept responsibilities of trust in good faith violate such trust. The three factors that constitute the fraud triangle are pressure, opportunity and rationalization. Abdullahi and Mansor (2015) assert that perceived pressure refers to the factors that lead to unethical behaviors. Every fraud perpetrator faces some pressure to commit fraud. These pressures can either be financial or non-financial pressures. Perceived opportunity is the second element necessary for fraud to occur. Opportunity is created by ineffective control or 
Journal DOI: www.doi.org/10.46654/RJMP

governance system that allows an individual to commit organizational fraud. In accounting, it is termed as weak internal control. The concept of perceived opportunity suggests that people will take advantage of circumstances available to them. Rationalization is the third element of the fraud triangle. This concept indicates that perpetrator must formulate some morally acceptable idea before engaging in unethical behavior. Rationalization refers to the justification and excuses that the immoral conduct is different from criminal activity. If an individual cannot justify dishonest actions, it is unlikely that he or she will engage in fraud.

Fraud Diamond Theory: According to Abdullahi and Mansor (2015), the fraud diamond theory was first presented by Wolfe and Hermanson in 2004. It is viewed as an expanded version of the fraud triangle theory. In this theory, a fourth element named 'capability' has been added to the three components of the fraud triangle. Although perceived pressure might coexist with an opportunity and a rationalization, it is unlikely for fraud to take place unless the fourth element (capability) is also present. In other words, the perpetrator must have the skills and ability to commit fraud. For example, the accountant can use his ability and skills in accounting to manipulate financial records and to commit financial fraud. According to Wolfe and Hermanson (2004), opportunity opens the doorway to fraud, and pressure and rationalization lead a person toward the door. However, capability enables the person to recognize the open doorway as an opportunity and to take advantage of it by walking through repeatedly.

Therefore, since the deontological ethical theory is focused on doing what is right in line with established principles, standards and rules, it becomes imperative for it to be adopted in this study. Accounting ethics are rules, principles, norms and standards that guide the conduct of accountants in a way that is ethically acceptable. The fraud diamond theory is also adopted in this study because of the fourth element introduced and added to the fraud triangle theory.

\section{Empirical Review}

Different studies have been conducted on accounting ethics and fraud. Oyebisi, Wisdom, Ayodotun, Abimbola, and Eche (2018) conducted a research on accounting ethics and the performance of accounting firms in Lagos, Nigeria. The study which adopted a survey research design with the use of primary source of data was analyzed using the Pearson product Moment Correlation Technique. It was discovered that accounting ethics has significant relationship with the performance of accounting firms in Nigeria. In a study conducted by Adegbie and Fofah (2016) on ethics, corporate governance and financial reporting in the Nigerian banking industry, using a survey research design with the use of structured questionnaire and analyzed using ANOVA, it was discovered that non-compliance with relevant ethical codes and poor corporate governance affected the preparation of quality and faithful financial reports. They therefore recommended among others that the Nigerian regulatory authorities should reorganize their monitoring and auditing systems to ensure ethical codes and corporate governance codes compliance. In a similar study conducted by Otalor and Eiya (2013), it was concluded that the professional accountant has a duty to maintain the reputation of the accounting profession by maintaining high ethical standards and consistently consider the interest of the public in any given assignment.

Okaro, Okafor and Ofoegbu (2013) in their study on corporate fraud in Nigeria using two case studies observed that top management were mainly the architects of fraud with accountants 
Journal DOI: www.doi.org/10.46654/RJMP

Article DOI: $\underline{\text { www.doi.org/10.46654/RJMP.1410 }}$

either involved or aiding it. This results in massive loss to investors and loss of employment by both perpetrators and innocent other employees.

Similar research studies examined fraud preventive measures and their effectiveness. For instance, Eme, Inyang and Udeme (2016) conducted a research on the effectiveness of the mechanisms of fraud prevention and detection in Nigeria, using quantitative data from accounting practitioners. The study identified several fraud prevention and detection mechanisms that are currently used in Nigeria such as system of internal controls, audits and ethical code of conduct. It was discovered that the current mechanisms of fraud prevention and detection are not proactive in dealing with the fraud menace. More proactive measures were recommended to be employed in tackling fraud in Nigeria. Gbegi and Adebisi (2015) conducted a similar research to analyse fraud detection and prevention strategies in the Nigerian public sector. Primary data was used through the administration of questionnaire and analysed using mean score. It was discovered that there is positive and significant relationship between management policies and fraud in the Nigerian public sector. It was also discovered that there is no strong internal control system in the Nigerian public sector and management integrity plays a key role in fraud prevention.

According Jafaru (n.d), in his research on strategies for fraud detection, prevention and deterrence, in order to curb the increasing rate of fraudulent practices in organisations and society, accounting ethics is an essential measure and strong control mechanism. Awareness of accountants about ethical values and practices should be improved upon through continuing education programmes. This will ensure full disclosure of relevant financial information and strict adherence to ethical codes by accountants. Javiriyah (2011) in his research on accounting fraud at WorldCom: the causes, consequences and the lessons learned, asserts that the accounting fraud that was perpetrated at WorldCom was as a result of lack of regards to ethics, honesty, or integrity. The accountants yielded to pressure to manipulate accounting records. The auditors too were not up to their responsibility of independent investigation of records in order to identify and report financial reporting fraud. Therefore, if accountants can adhere to accounting ethical codes of conduct, accounting fraud will be minimized and the reputation of the accounting profession will be restored.

\section{METHODOLOGY}

This study employs a survey research design aimed at examining the imperative of accounting ethics in the adoption of fraud preventive measures in Nigeria. Questionnaire was used by the researcher to collect primary data from fifty (50) respondents. Professional accountants and accounting academics in Nigeria were the target of this study. The questionnaires were distributed hand-to-hand to the target groups. A total of 50 responses were retrieved which represents $100 \%$ response rate. Participants were asked questions related to the role accounting ethics play in the adoption of fraud preventive measures in Nigeria. The agreement ratings were made on a 5-point Likert scale ranging from 1 (strongly disagree) to 5 (strongly agree). The data collected was analyzed using Descriptive statistics tools such as tables, frequency distribution and percentages. Spearman's Nonparametric Correlation was used to test the hypotheses using SPSS. 
Journal DOI: www.doi.org/10.46654/RJMP

Article DOI: www.doi.org/10.46654/RJMP.1410

\section{RESULTS AND DISCUSSIONS}

Primary data for the study was analyzed using Descriptive statistics and inferential statistics via SPSS. The statistics of the respondents Bio data and the statistics of response for the various questions are stated below.

\section{Table 1: Respondents Bio Data.}

\begin{tabular}{|c|c|c|c|}
\hline & Characteristics & Frequency & Percentage $(\%)$ \\
\hline 1 & \multicolumn{3}{|c|}{ Profession } \\
\hline & Practicing professional accountants & 27 & 54 \\
\hline & Accounting lecturers & 23 & 46 \\
\hline & Total & 50 & 100 \\
\hline 2 & \multicolumn{3}{|c|}{ Gender } \\
\hline & Female & 18 & 36 \\
\hline & Male & 32 & 64 \\
\hline & Total & 50 & 100 \\
\hline 3 & \multicolumn{3}{|c|}{ Level of Education } \\
\hline & Bachelor degree & 17 & 34 \\
\hline & Master degree & 15 & 30 \\
\hline & $\mathrm{PhD}$ & 18 & 36 \\
\hline & Total & 50 & 100 \\
\hline 4 & \multicolumn{3}{|c|}{ Years of Experience } \\
\hline & $0-5$ years & 4 & 8 \\
\hline & 6-10 years & 12 & 24 \\
\hline & 11-15 years & 22 & 44 \\
\hline & More than 15 years & 12 & 24 \\
\hline & Total & 50 & 100 \\
\hline 5 & \multicolumn{3}{|c|}{ Professional qualification } \\
\hline & ICAN & 30 & 60 \\
\hline & ACCA & 5 & 10 \\
\hline & ANAN & 15 & 30 \\
\hline & Total & 50 & 100 \\
\hline
\end{tabular}

Source: Author's computation using SPSS 
Journal DOI: www.doi.org/10.46654/RJMP

Article DOI: $\underline{\text { ww.doi.org/10.46654/RJMP.1410 }}$

\section{Table 2: Frequency Statistics}

Internal control as a fraud preventive measure can only be effective if accountants maintain high level of integrity and professional competence (Fraud preventive measures)

\begin{tabular}{|ll|r|r|r|r|}
\hline & & & & \multicolumn{2}{c|}{$\begin{array}{c}\text { Cumulative } \\
\text { Percent }\end{array}$} \\
\hline Valid & Agree & 8 & 16.0 & 16.0 & 16.0 \\
& Strongly agree & 42 & 84.0 & 84.0 & 100.0 \\
& Total & 50 & 100.0 & 100.0 & \\
\hline
\end{tabular}

Accounting ethics plays a critical role in the designing of an effective internal control system (Accounting ethics)

\begin{tabular}{|ll|r|r|r|r|}
\hline & & & & \multicolumn{2}{c|}{$\begin{array}{c}\text { Cumulative } \\
\text { Percent }\end{array}$} \\
\hline Valid & Agree & 8 & 16.0 & 16.0 & 16.0 \\
& Strongly agree & 42 & 84.0 & 84.0 & 100.0 \\
& Total & 50 & 100.0 & 100.0 & \\
\hline
\end{tabular}

Internal and external audit as fraud preventive measures can only achieve their objective if ethical standards are maintained by accounting professionals (Fraud preventive measures)

\begin{tabular}{|ll|r|r|r|r|}
\hline & & & & \multicolumn{2}{c|}{ Cumulative } \\
& & Frequency & Percent & Valid Percent & \multicolumn{2}{|c|}{ Percent } \\
\hline Valid & Agree & 12 & 24.0 & 24.0 & 100.0 \\
& Strongly agree & 38 & 76.0 & 76.0 & \\
& Total & 50 & 100.0 & 100.0 & \\
\hline
\end{tabular}

Accounting ethics is the foundation for an effective internal and external audit (Accounting ethics)

\begin{tabular}{|ll|r|r|r|r|}
\hline & & & & \multicolumn{2}{c|}{$\begin{array}{c}\text { Cumulative } \\
\text { Percent }\end{array}$} \\
\hline Valid & Agree & 11 & 22.0 & 22.0 & 22.0 \\
& Strongly agree & 39 & 78.0 & 78.0 & 100.0 \\
& Total & 50 & 100.0 & 100.0 & \\
\hline
\end{tabular}


Journal DOI: www.doi.org/10.46654/RJMP

Article DOI: $\underline{\text { ww.doi.org/10.46654/RJMP.1410 }}$

\section{Ethical compliance by accountants prevents accounting fraud}

\begin{tabular}{|c|c|c|c|c|c|}
\hline & & Frequency & Percent & $\begin{array}{c}\text { Valid } \\
\text { Percent }\end{array}$ & $\begin{array}{c}\text { Cumulative } \\
\text { Percent }\end{array}$ \\
\hline \multirow[t]{5}{*}{ Valid } & Disagree & 3 & 6.0 & 6.0 & 6.0 \\
\hline & Neutral & 3 & 6.0 & 6.0 & 12.0 \\
\hline & Agree & 9 & 18.0 & 18.0 & 30.0 \\
\hline & Strongly agree & 35 & 70.0 & 70.0 & 100.0 \\
\hline & Total & 50 & 100.0 & 100.0 & \\
\hline
\end{tabular}

Non-compliance with ethical codes by accountants can lead to fraudulent acts

\begin{tabular}{|c|c|c|c|c|c|}
\hline & & Frequency & Percent & $\begin{array}{l}\text { Valid } \\
\text { Percent }\end{array}$ & $\begin{array}{c}\text { Cumulative } \\
\text { Percent }\end{array}$ \\
\hline \multirow[t]{3}{*}{ Valid } & Agree & 10 & 20.0 & 20.0 & 20.0 \\
\hline & Strongly agree & 40 & 80.0 & 80.0 & 100.0 \\
\hline & Total & 50 & 100.0 & 100.0 & \\
\hline
\end{tabular}

Source: Author's computation using SPSS

Table 1 above shows the frequency distribution of the personal information of the respondents, which include profession, gender, level of education, years of experience and professional qualification.

Table 2 above shows the frequency distribution of the respondents with respect to the six questions contained in the questionnaire using the Likert 5 point scale of strongly agree (5), agree (4), neutral (3), disagree (2), and strongly disagree (1).

From the frequency obtained above for each of the questions, it is clear that the respondents' answers range from strongly agree to agree, with only question 5 having $6 \%$ of respondents disagreeing and $6 \%$ neutral. Hence, from the high frequency and percentage rate obtained from the respondents who strongly agreed and agreed using the Likert scale, it can be deduced that accounting ethics is imperative in the adoption of fraud preventive measures in Nigeria. 
Journal DOI: www.doi.org/10.46654/RJMP

Article DOI: $\underline{\text { www.doi.org/10.46654/RJMP.1410 }}$

\section{Table 3: Nonparametric Correlations for Hypothesis 1}

\begin{tabular}{|c|c|c|c|}
\hline & & $\begin{array}{l}\text { Internal control as } \\
\text { a fraud preventive } \\
\text { measure can only } \\
\text { be effective if } \\
\text { accountants } \\
\text { maintain high level } \\
\text { of integrity and } \\
\text { professional } \\
\text { competence } \\
\text { (Fraud preventive } \\
\text { measures) }\end{array}$ & $\begin{array}{l}\text { Accounting ethics } \\
\text { plays a critical role } \\
\text { in the designing of } \\
\text { an } \quad \text { effective } \\
\text { internal control } \\
\text { system } \\
\text { (Accounting ethics) }\end{array}$ \\
\hline \multirow[t]{3}{*}{ Spearman's rho } & $\begin{array}{l}\text { Internal control as a fraud Correlation Coefficient } \\
\text { preventive measure can only be } \\
\text { effective if accountants maintain Sig. (2-tailed) } \\
\text { high level of integrity and } \\
\text { professional competence (Fraud } \mathrm{N} \\
\text { preventive measures) }\end{array}$ & $\begin{array}{l}1.000 \\
50\end{array}$ & $\begin{array}{l}1.000 \\
50\end{array}$ \\
\hline & $\begin{array}{l}\text { Accounting ethics plays a critical Correlation Coefficient } \\
\text { role in the designing of an } \\
\text { effective internal control system Sig. (2-tailed) } \\
\text { (Accounting ethics) }\end{array}$ & $1.000^{* x}$ & 1.000 \\
\hline & $\mathrm{N}$ & 50 & 50 \\
\hline
\end{tabular}

${ }^{* *}$. Correlation is significant at the 0.01 level (2-tailed).

Table 3 above shows the result of correlation analysis between the respondents' responses regarding the relationship between accounting ethics and effective internal control. The spearman correlation results indicate a perfect correlation at $1 \%$ level of significance. This means that internal control system as a fraud preventive measure can only be effective if accountants maintain high level of integrity and professional competence. 
Journal DOI: www.doi.org/10.46654/RJMP

Table 4: Nonparametric Correlations for Hypothesis 1

\begin{tabular}{|c|c|c|c|c|}
\hline & & & $\begin{array}{c}\text { Internal and } \\
\text { external audit as } \\
\text { fraud preventive } \\
\text { measures can only } \\
\text { achieve their } \\
\text { objective if ethical } \\
\text { standards are } \\
\text { maintained by } \\
\text { accounting } \\
\text { professionals } \\
\text { (Fraud preventive } \\
\text { measures) }\end{array}$ & $\begin{array}{c}\text { Deth } \\
\text { Accounting ethics } \\
\text { is the foundation } \\
\text { for an effective } \\
\text { external audit } \\
\text { (Accounting ethics) }\end{array}$ \\
\hline \multirow[t]{2}{*}{ Spearman's rho } & $\begin{array}{l}\text { Internal and external audit as } \\
\text { fraud preventive measures can } \\
\text { only achieve their objective if } \\
\text { ethical standards are maintained } \\
\text { by accounting professionals } \\
\text { (Fraud preventive measures) }\end{array}$ & $\begin{array}{l}\text { Correlation Coefficient } \\
\text { Sig. (2-tailed) } \\
\mathrm{N}\end{array}$ & $\begin{array}{r}1.000 \\
50 \\
.\end{array}$ & $\begin{array}{r}.832 \\
.000 \\
50\end{array}$ \\
\hline & $\begin{array}{l}\text { Accounting ethics is the } \\
\text { foundation for an effective } \\
\text { internal and external audit } \\
\text { (Accounting ethics) }\end{array}$ & $\begin{array}{l}\text { Correlation Coefficient } \\
\text { Sig. (2-tailed) } \\
\mathrm{N}\end{array}$ & $\begin{array}{r}.832^{*+} \\
.000 \\
50\end{array}$ & $\begin{array}{r}1.000 \\
50\end{array}$ \\
\hline
\end{tabular}

${ }^{* *}$. Correlation is significant at the 0.01 level (2-tailed).

Table 4 above shows the result of correlation analysis between the respondents' responses regarding the relationship between accounting ethics and effective internal and external audit. The spearman correlation results indicate a strong positive correlation at $1 \%$ level of significance. This means that accounting ethics is the foundation for effective internal and external audit as fraud preventive measures.

Therefore, the null hypothesis (Accounting ethics does not play significant role in the adoption of fraud preventive measures in Nigeria) is rejected. 
Journal DOI: www.doi.org/10.46654/RJMP

Table 5: Nonparametric Correlation for Hypothesis 2

\begin{tabular}{|c|c|c|c|c|}
\hline & & & $\begin{array}{c}\text { Ethical compliance } \\
\text { by accountants } \\
\text { prevents } \\
\text { accounting fraud }\end{array}$ & $\begin{array}{l}\text { Non-compliance } \\
\text { with ethical codes } \\
\text { by accountants } \\
\text { can lead to } \\
\text { fraudulent acts }\end{array}$ \\
\hline \multirow[t]{2}{*}{ Spearman's rho } & $\begin{array}{l}\text { Ethical compliance by } \\
\text { accountants prevents accounting } \\
\text { fraud }\end{array}$ & $\begin{array}{l}\text { Correlation Coefficient } \\
\text { Sig. (2-tailed) } \\
\mathrm{N}\end{array}$ & $\begin{array}{r}1.000 \\
50\end{array}$ & $\begin{array}{r}.245 \\
.087 \\
50\end{array}$ \\
\hline & $\begin{array}{l}\text { Non-compliance with ethical } \\
\text { codes by accountants can lead } \\
\text { to fraudulent acts }\end{array}$ & $\begin{array}{l}\text { Correlation Coefficient } \\
\text { Sig. (2-tailed) } \\
\mathrm{N}\end{array}$ & $\begin{array}{r}.245 \\
.087 \\
50\end{array}$ & $\begin{array}{r}1.000 \\
50\end{array}$ \\
\hline
\end{tabular}

Table 5 above shows the result of correlation analysis between the respondents' responses regarding the relationship between ethical compliance and fraud. The spearman correlation results indicate a positive correlation at $1 \%$ level of significance. This means that ethical compliance by accountants can prevent fraudulent acts. Therefore, the null hypothesis (compliance with ethical codes does not prevent the occurrence of fraud) is rejected.

Findings from hypothesis one shows that accounting ethics play significant role in the adoption of fraud preventive measures in Nigeria. The effectiveness of other fraud preventive measures (for example, strong internal control, effective internal and external audit, policies and procedures that minimizes the opportunity and pressure to commit fraud) depends to a large extent on the accountants compliance to ethical code of conduct, since accountants are trustees and custodians of the financial resources and assets of organizations.

Findings from hypothesis two reveal that compliance with ethical codes prevents the occurrence of fraud. Hence, strict enforcement by relevant professional bodies will increase the compliance level, thereby reducing the incidences of fraud in Nigeria.

These findings support the findings of Oyebisi, Wisdom, Ayodotun, Abimbola, and Eche (2018);Eme, Inyang and Udeme (2016); Gbegi and Adebisi (2015); Jafaru (n.d); and Javiriyah (2011) who all discovered positive relationship between accounting ethics and fraud prevention in Nigeria. 
Journal DOI: www.doi.org/10.46654/RJMP

Article DOI: $\underline{\text { www.doi.org/10.46654/RJMP.1410 }}$

\section{CONCLUSION AND RECOMMENDATIONS}

This study examined the imperative of accounting ethics in the adoption of fraud preventive measures in Nigeria. It is therefore concluded that if accountants discharge their duties and responsibilities in accordance with the requirements of the professional code of conduct, other fraud preventive measures will be more effective, the incidence of fraud and corporate failure will be minimized, and the reputation of the accounting profession will be enhanced.

Based on the findings of this study, three main recommendations are made:

1. Corporate organisations should develop strong measures for fraud prevention. In developing such measures, accountants should be encouraged and given the platform to discharge their responsibilities in accordance with the provisions of the accountants' code of ethics without any undue influence or pressure from management.

2. Corporations should have a corporate culture of ethical principles that holds both management and other personnel strictly accountable for the compliance with these principles and enforcement of disciplinary actions for any violation across all levels of the organization.

3. Accounting bodies should put in place strict monitoring and disciplinary measures that will ensure compliance with ethical principles. This will restore the confidence and reputation of the accounting profession as trustees and watchdogs of the society. 
Journal DOI: www.doi.org/10.46654/RJMP

Article DOI: $\underline{\text { ww.doi.org/10.46654/RJMP.1410 }}$

\section{REFERENCES}

Abiola, I., and Oyewole, A.T. (2013). Evaluation of the Effect of Monitoring and Control Activities on Fraud Detection in Selected Nigerian Commercial Banks. Research Journal of Finance and Accounting, 4(6), 57-63.

Adegbie, F.F., and Fofah, E.T. (2016). Ethics, Corporate Governance and Financial Reporting in the Nigerian Banking Industry: Global Role of International Financial Reporting Standards. Accounting and Finance Research, 5(1), 50-63.

Adeniji, A.A. (2004). Auditing and Investigation, Lagos: Value Analysis Consult.

Akani, N.F., and Oladutire, E.O. (2013). Fraud Prevention, Mitigation and Management Practices $\quad$ in Nigerian Firms. Journal of Business and Management, 11(3), 07-14.

Center for Audit Quality (2010). Deterring and Detecting Financial Reporting Fraud: A Platform for Action. Retrieved from https://www.ceic.gouv.qc.ca/fileadmin/Fichiers_client/centre_documentaire/CEIC-R3517_01.pdf

Efiong, E.J., Inyang, I.O., and Joshua, U. (2016). Effectiveness of the Mechanisms of Fraud Prevention and Detection in Nigeria. Advances in Social Science Research Journal, 3(3), 206-217.

Enofe, A.O., Okpako, P.O., and Atube (2013). The Impact of Forensic Accounting on Fraud Detection. European Journal of Business and Management, 5(26), 61-72.

Ernst \& Young (n.d). Fraud Prevention, Detection and Response. Retrieved from https://fliphtml5.com/bpek/kkuc/basic

Gbegi, D.O. and Adebisi, J.F. (2015). Analysis of Fraud Detection and Prevention Strategies in the Nigerian Public Sector. Journal of Good Governance and Sustainable Development in Africa, 2(4), 109-128.

Hamilton, D.I., and Odinioha, J.M.G. (2012). Dimensions of Fraud in Nigerian Quoted Firms. American Journal of Social and Management Sciences, 3(3), 112-120.

ICAN (2014). Management, Governance and Ethics, United Kingdom: Emile Woolf International.

IFAC (2013). Handbook of the Code of Ethics for Professional Accountants. International ethics Standard Board for Accountants. Retrieved from https://www.ifac.org/system/files/publications/files/2013-IESBA-Handbook.pdf

James, A.H. (2004). Ethics, Fraud, and Internal Control. Accounting Information Systems $\left(4^{\text {th }}\right.$ Ed.), USA: South-Western Publishing Co.

Javiriyah, A. (2011). The Accounting Fraud @ WorldCom: The Causes, Chaateristics, Consequences, and the Lessons Learned (Doctoral Thesis, University of Central Florida, Orlando, Florida). Retrieved from 
Journal DOI: www.doi.org/10.46654/RJMP

Article DOI: www.doi.org/10.46654/RJMP.1410

https://stars.library.ucf.edu/cgi/viewcontent.cgi?article=2106\&context=honorstheses 1990 $-2015$

Jimoh, J. (n.d). Strategies for Fraud Detection, Prevention and Deterrence. International Journal of Research Development. Retrieved from http://www.globalacademicgroup.com/journals/approaches/Strategies\%20for\%20Fraud \%20Detection.pdf

Kyalo, S.M., Kalio, A.M., and Ngahu, S. (2012). Role of Fraud Prevention in Enhancing Effective Financial Reporting in County Governments in Kenya. International Journal of Science and Research, 3(1), 2108-2114.

Mock, J.M. (2004). Classic Case Studies in Accounting Fraud (Doctoral thesis, Miami University). Retrieved from https://etd.ohiolink.edu/!etd.send_file\%3Faccession\%3Dmuhonors1111004894\%26dispo sition\%3Dinline

Neringa, S. and Justina, N. (2013). Formation of the Ethics of Professional Accountants from a Moral Standpoint: Analysis of Decisive Factors and their Influence. European Scientific Journal, 1(1), 106-115.

Nickolas, S. (2015). What is Accounting Fraud? Retrieved from https://www.investopedia.com/ask/answers/032715/what-accounting-fraud.asp

Nwagboso, J.C. (2012). The imperative of Adhering to Professional Code of Ethical Conduct. African Accounting \& Finance Association (2 ${ }^{\text {nd }}$ Annual Conference), 111-133.

Ogbonna, G.N., and Appah, E. (2011). Ethical Compliance by the Accountant on the Quality of Financial Reporting \& Performance of Quoted Companies in Nigeria. Asian Journal of Business management, 3(3), 152-160.

Okaro, S.C., Okafor, G.O., and Ofoegbu, G. (2013). Corporate Fraud in Nigeria- A Two Case Study. International Journal of Research in Management, 6(3), 9-17.

Okwuduche, C. (2016). Accounting Fraud: Meaning, Types and Characteristics. Retrieved from https://accountantnextdoor.com/what-is-accounting-fraud-meaning-types-andcharacteristics/

Otalor, J.I., and Eiya, O. (2013). Ethics in Accounting and the Reliability of Financial Information. European Journal of Business and Management, 5(13), 73-81.

Otusanya, O.J., Lauwo, S., and Hayati, A.K.A. (2012). The Culpability of Accounting Practice in Promoting Bribery and Corruption in Developing Countries. African Accounting \& Finance Association (2 ${ }^{\text {nd }}$ Annual Conference), 74-95.

Oyebisi, M.I., Wisdom, O., Ayodotun, I., Abimbola, J., and Eche, O. (2018). Accounting Ethics and the Performance of Accounting Firms in Lagos, Nigeria. Journal of Finance and Marketing, 2(2), 10-16. 
Journal DOI: www.doi.org/10.46654/RJMP

Article DOI: $\underline{\text { ww.doi.org/10.46654/RJMP.1410 }}$

Reynolds, P., and Gavagni, M. (2015). Fraud Prevention, Internal Controls and Ethics. Retrieved from https://www.nahc.org/wp-content/uploads/2017/10/FM15-701.pdf

Yinka, M.S., Jide, I., and Emmanuel, I.C. (2015). Unethical Accounting Practice and Financial Reporting Quality: Evidence from Nigeria. International Journal of Academic Research in Accounting, Finance and Management Sciences, 5(2), 143-150.

Yuquan, Y. (2015). Accounting Fraud Motivation. Celebrating Scholarship and Creativity Day. Paper 44. Retrieved from http://digitalcommons.cbsju.edu/elce_cscday/44. 